\title{
WAREHOUSE SALE CONTRACT FROM AL-FAYYŪM FROM THE YEAR 371 AH / 981 CE
}

\author{
Ahmed KAMAL ${ }^{1}$ and Tamer MOKTAR ${ }^{2}$ \\ ${ }^{1}$ Ministry of Antiquities, Egypt \\ abokamal_85@yahoo.com \\ ${ }^{2}$ Helwan University, Egypt \\ tameermokhtar@gmail.com
}

\begin{abstract}
Most preserved Arabic documents come from al-Fayyūm. The publication and study of these documents rewrites the history of this region in the early Islamic era. Among the topics recorded on these documents are sales contracts, revealing one important practical application of the Islamic law.

This article aims to publish and discuss a warehouse makhzan and a portico usțuwān sale contract, currently preserved at the Museum of Islamic Art in Cairo and dated $371 \mathrm{AH} / 981 \mathrm{AD}$. These are compared to similar published contracts and the data provided in legal handbooks.
\end{abstract} إتنتمي معظم الوثائق العربية الباقية إلى الفيوم. ويمكن

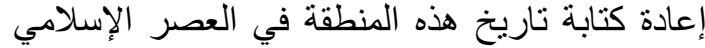

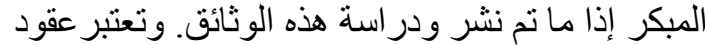

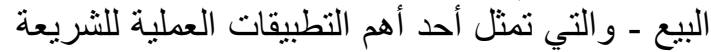
الإسلامية ـ - من بين أهم الموضو عات التي سجلتها هذه الوثائق.

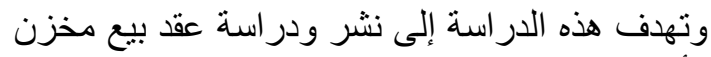
وأسطوان محفوظ حاليًا في متحف الفئ الفن الإسلامي

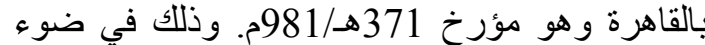
الوثائق المشابهة المنشورة وما ورد وردي في كتب الفقه الإسلامي عن هذا النوع من الوثائق.

\section{KEYWORDS}

Arabic papyri- al-Fayyūm- Contract- Legal documents- Warehouse.

$$
\text { البرديات العربية- الفيوم- عقود- وثائق قانونية- }
$$

\section{INTRODUCTION}

In the Museum of Islamic Art, the contract of a warehouse makhzan and a portico usțuwān sale is preserved, without its origin being known. ${ }^{1}$ The Museum's records mention that this document was among a group of manuscripts extracted from under the warehouse ladder of the Museum of Islamic Art in 1949. It can be attributed to alFayyūm thanks to the text indicating that the sellers and the buyer are from the village of Buljusūq, one of al-Fayyūm's ancient villages. According to al-Nābulsī, Buljusūq was a large town located in the south of al-Fayyūm, with the mosque and church ruins. ${ }^{2}$

\footnotetext{
${ }^{1}$ Abbreviations for Arabic documents are those of the checklist of Arabic documents, available online at http://www.naher-osten.Imu.de/isapchecklist (Accessed March 3, 2021). Also, we would like to thank the reviewers for their valuable comments.

${ }^{2}$ Al-Nābulsī, Tarikh al-Fayyūm, 18, 82; 'Abd al-Lațîf, Al-Mudun wa-l-qurā, 176-177.
} 
This place was also mentioned in the book al-Tuhfa al-Saniyya, distorted into Buljūq. ${ }^{1}$ It has now disappeared; on its ruins was built a modern village called Qasr al-Bāsil, one of Ița district villages in al-Fayyūm Governorate. ${ }^{2}$

Many sale properties contracts from Buljusūq have been published. ${ }^{3}$ As yet, this is the first warehouse sale contract examined. ${ }^{4}$ Moreover, the contract in question include the sale of a portico al-ustuwān, located in front of this warehouse. The sale of this type of property is not ordinary in Arabic papyri. The ustuwān is only mentioned in another document from the same village. ${ }^{5}$

As indicated on line 6, the warehouse is part of the buyer's house, Yuhannis, son of Bī' a Lūlū. This could indicate that he sold this half warehouse earlier and then repurchased it.

The Greek and Coptic formulas locally used at the time of the Islamic conquest of Egypt influenced the Arabic formulas recorded later, as seen in this contract. ${ }^{6}$ These were adjusted to conform to Islamic law. ${ }^{7}$ It follows the standard Arabic real estate contract formula, ${ }^{8}$ beginning with the Basmalla, then the names of the buyer and sellers. It is also indicated that they were all residents of Buljusūq. In the next lines, the writer determines that what is being sold is half of the warehouse in the buyer's house and the ustuwān in front of it, as well as defining the four limits. It is said that the seller has paid the total price, which is a dinar and a third, and that the buyer now possesses half of the warehouse and the ustuwān, and he can dispose of them as he wants. The contract date follows Jumada I 371/ 2 November 981-1 December 981. Six witnesses testify for this contract in their own handwriting. ${ }^{9}$ Although the names of the buyer and sellers are Coptic, all of the witnesses are Muslim. ${ }^{10}$ Also, the contract does not contain the guarantee clause, which rarely disappeared from the contracts, ${ }^{11}$ perhaps because the warehouse is located inside the buyer's home.

\footnotetext{
${ }^{1}$ Ibn al-Jī'ān, Al-Tuhfa al-Sanīa, 153.

${ }^{2}$ Ramzī, Al-Qāmūs al-Jughrāfì , first section, 167-168.

${ }^{3}$ P.FahmiTaaqud 8, 339/951, Bulğusūq; P.Cair.Arab I 60, 406/1015-1016, unknown (al-Fayyūm); P.Cair.Arab I 61, 423/1032, unknown (al-Fayyūm); P.Cair.Arab I 62, 429/1037-1038, unknown (alFayyūm); P.Cair.Arab. I 67, 450/1058, unknown (al-Fayyūm). Although it is not known where some of these documents were found, their texts indicated that the parties to the contracts were residents of the village of Buljusūq.

${ }^{4}$ This does not mean that the warehouses are not mentioned in other Arabic documents: P.JoySorrow 36 verso, $1^{\text {st }}-2^{\text {nd }} / 7^{\text {th }}-8^{\text {th }} c$. , unknown (Egypt); CPR XVI $19.5,1^{\text {st }}-2^{\text {nd }} / 7^{\text {th }}-8^{\text {th }} c$. , unknown (Egypt); P.Cair.Arab I 74 .1, 344/955, unknown (Egypt); P.GenizahCambr. 132 .10, 401/1011-1012, al-Fusțāt.

${ }^{5}$ P.Cair.Arab I 63. 4, 434/1043, unknown (al-Fayyūm)

${ }^{6}$ Caliph 'Umar ibn 'Abd al-'azīz (99-101 / 717-720) ordered Muslims to rule in the Egyptian cases instead of the local Egyptian governors "pagarch". The Arabs began to settle disputes based on contracts written in Coptic and Greek, giving them extensive knowledge of their formulas. Al-Kindī, al-Wulāt, p. 53; Gladys, “A Comparison”, Part II, pp. 100-114; Foss, “Egypt under Mu'āwiya”, Part I, 11.

${ }^{7}$ Fahmī, Wathaiq, 5.

${ }^{8}$ The Shurūt books mention many details on the definition of the basic elements and formulas that must be used in writing sales contracts of all kinds and cases. Al-Asyūtīi, Jawāhir, vol 1, 75; Al-Tahāwī, AlShurūt al-Saghīr, vol 1, 4-354.

${ }^{9}$ By having witnesses, the sale document becomes a legitimate document acceptable in every circumstance. 'Ibrāhīm, “Al-Tawthīqāt”, 300-305.

${ }^{10}$ Copts accept Arab contracts as an effective way to deal with important matters. Gladys, "A Comparison", Part I, 223.

${ }^{11}$ Gladys points to the existence of the guarantee clause, which is the seller's acknowledgement that he is responsible, not the buyer, in the event of any claim from a third party in Demotic contracts, as well as in the remaining Greek contracts from the Roman and Byzantine periods. She also mentions that
} 


\section{EDITION}

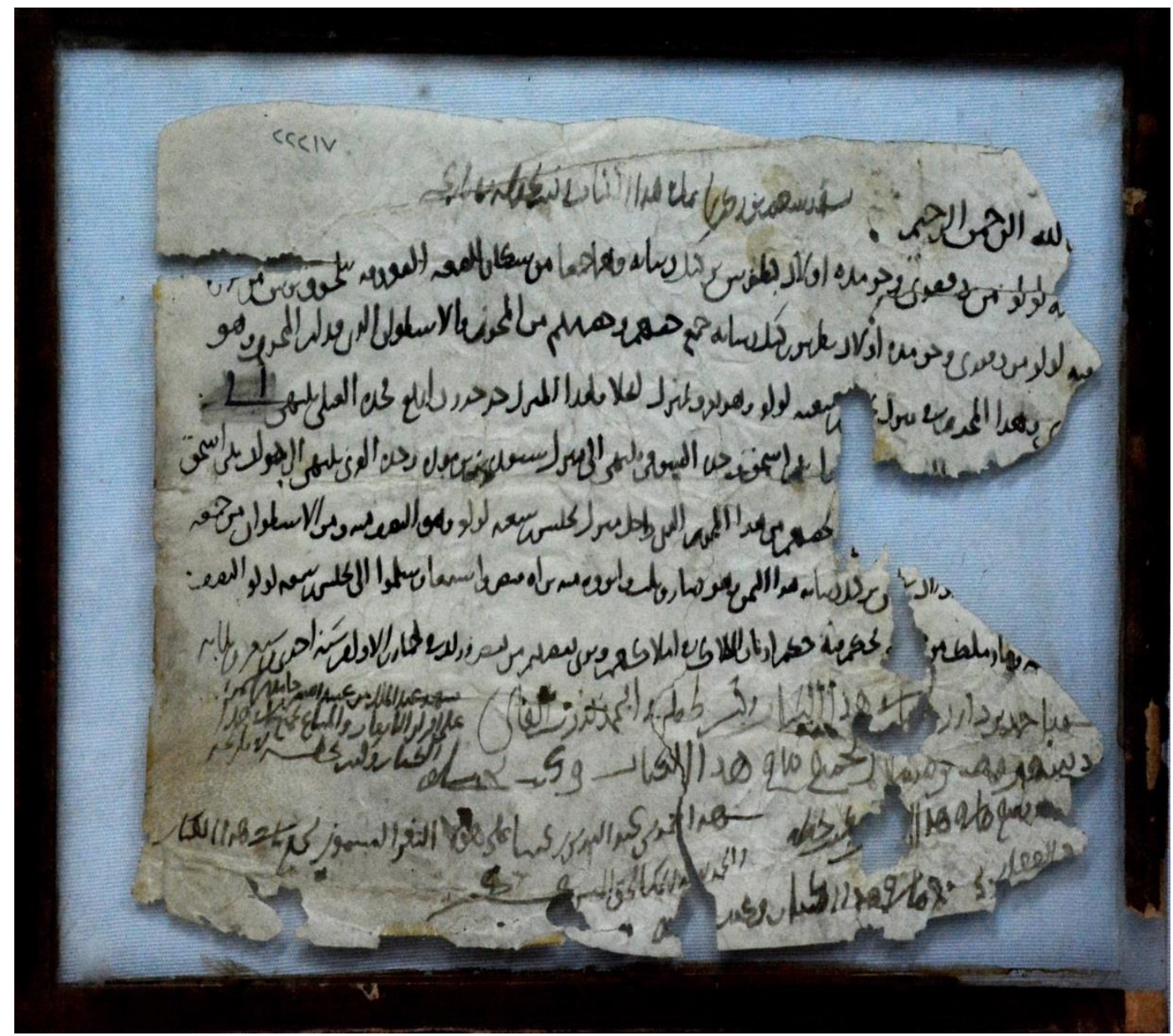

Fig. 1. P.Cair.IslArt inv. 21777

P.Cair.IslArt inv. $21777 \quad 26 \times 18 \mathrm{~cm} \quad$ Parchment Jumada I 371

2 November 981-1 December 981

The document is a sheet of yellowish-white parchment. The recto shows 13 lines in black ink with a medium-thickness pen, while the verso has no text. The main text takes place in the first eight lines, and the remaining lines are the testimony of witnesses. Since the remaining space was not enough to record all the names of the witnesses, one of them recorded his in the space that was initially left blank next to the basmalla in the first line. Another wrote his testimony on the left side of the sheet in three lines, corresponding to the ninth and tenth lines. The first eight lines are written in dark black ink, but the witnesses' testimonies are in slightly faded black ink. Eight different hands wrote the text: the writer of the main text, who may have been experienced, and the seven witnesses.

The right side of this document is severely damaged, causing a large part of the text to be lost at the beginning of the fifth and sixth lines. A minor part is lost in line seven. As document: P.Berl.Arab. I 10 b, 405/1015, unknown (Egypt). Gladys, “A Comparison”, Part IV, 274-275. 
for the rest of the document, the missing words on the right range from one to four words. There is also a small cut at the second line of the text on the right side of the parchment that extends from the beginning of the document from this side to the third word of the remaining text, but it did not cause any part of the text to be lost. Also, in the same line, there is another small cut on the left side, which causes the upper part of the letters of the last word to be lost. Another cut is approximately in the middle of the document. It starts from the bottom, extending vertically up to line ten, causing the loss of some of the letters of the last word from line twelve, and slightly affecting some of the letters of other lines' words. The document has some small holes that caused the loss of some letters on the right side of the document from the seventh to the eleventh line. Otherwise, the rest of the sheet is in good condition of preservation. There are some ink spots, but they do not affect the text; one of them is next to the basmalla on the first line, and two other spots on lines nine and eleven and two other spots below line eleven and after the end of line twelve. The writer left some space at the top of the sheet and the end of the text on the left side. He left a small space at the bottom of the sheet. Since the sheet was cut off on the right side, we cannot know how much text is missing on this side. Points were used in a few words, but no diacritics except for the Fatha above Sin in the word sana at the end of line eight. The writer made a grammatical mistake by using the formula for double instead of the plural of the word wa-huma in line two.

The backward bending $y \bar{a}$ ' characterises the hand-writing of the main text as in $f \hat{l}$, 'ila at the end of line four, and $f i$ at line eight. The Lam at the end of the word is a horizontal line extending below the beginning of the next word; for the $K \bar{a} f$ at the beginning of the word, the writer placed the upper stroke separately, as in the name of the seller Kayl in lines two and three. Some words are also connected. As for the witnesses' lines, we find that on line nine, the witness neglected to write the $H \bar{a}^{2}$ of Allah and the two letters Mìm and Nūn of al-'àlamìn.

\section{TEXT:}

$$
\begin{aligned}
& \text { 1. [بسم] الله الرحمن الرحيم (فر اغ) شهد سعيد بن زكريا بما في هذا الكتاب وكتب بخطه في تاريخه } \\
& \text { 2. [هذا ما اشترى يحنس بن بيح-]ـه لولو من دفقدي وحر مده او لاد بطرس بن كيل وبناته و هــــاــ جميعا من }
\end{aligned}
$$

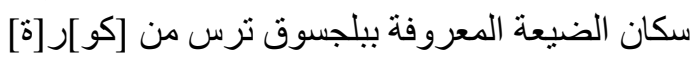

$$
\begin{aligned}
& \text { 3. [ الفيوم اشترى يحنس بن بـ]يعه لولو من دفقدى وحرمده او لاد بطرس بن كيل وبناته جميع حقهم وحصتهم وهن }
\end{aligned}
$$

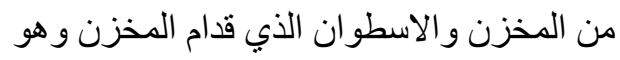

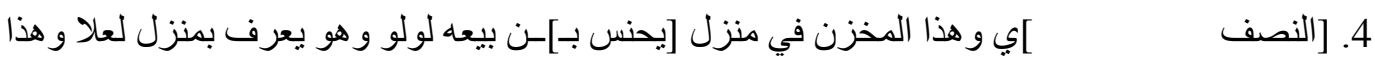

$$
\begin{aligned}
& \text { المنزل لله حد حدود أربع فحده القبلي ينتهي الى الى في }
\end{aligned}
$$

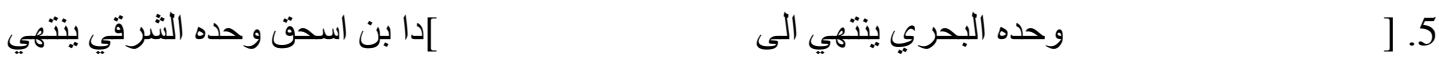

$$
\begin{aligned}
& \text { الى منزل شنوده بن برموده وحده الغربي ينتهي الى جو اري بنى الى اسحق }
\end{aligned}
$$

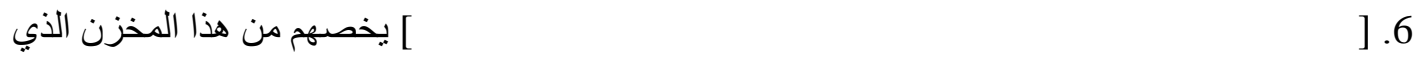

$$
\begin{aligned}
& \text { داخل منزل يحنس بن بيعه لولو وهو النصف منه ومن الاسطوان من جميعه } \\
& \text { 7. }
\end{aligned}
$$

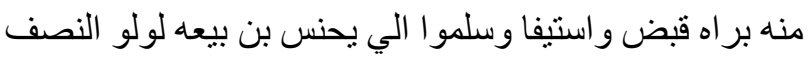




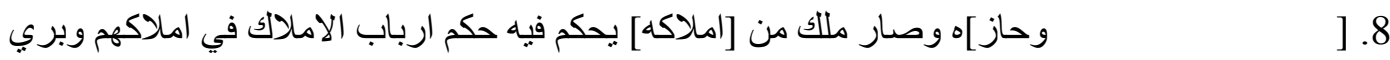

$$
\begin{aligned}
& \text { بعضهم من بعض وذللك في جمادى الأول من سنة احدى وسبعين وتلثمايه } \\
& \text { 9. [ثـ] مهد احمد بن دار [ي بجميع مـ] في هذا الكتاب وكتب بخطه و الحمد للا>هـ> رب العالـميب>ن } \\
& \text { 10. [ ق] شهد فهد بن مسا[ف]]-ر بجميع ما في هذا الكتاب وكتب بخطه }
\end{aligned}
$$

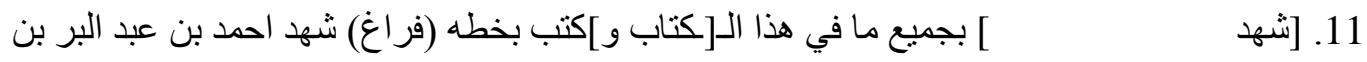

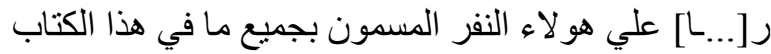

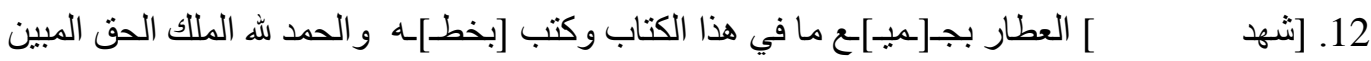

$$
\begin{aligned}
& \text { بخطه }
\end{aligned}
$$

\section{Witness's signature opposite to lines 9-10:}

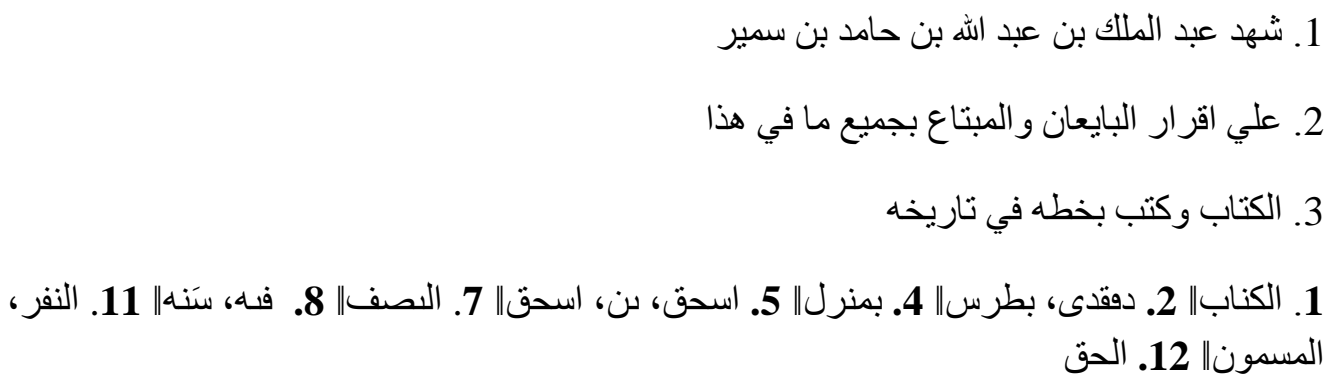

1. [In the name] of Allah, the Compassionate, the Merciful. (Vacat) Sa'îd son of Zakaryā had witnessed to all that is contained in this contract and he has written in his own handwriting on this date.

2. [This is, what Yuhannis son of $\left.\mathrm{B}^{\prime}{ }^{`}\right] \mathrm{a}$ Lūlū bought from Dafqadī and Harmada, the sons of Butrus son of Kayl and his daughters, and they all from the inhabitants of the domain known as Buljusūq Tirs, of the [dis]tri[ct] of

3. [Al-Fayyūm. Yuhannis son of B] $\bar{i}^{\top}$ a Lūlū bought from Dafqadī and Harmada, the sons of Butrus son of Kayl and his daughters all their rights and their share of the warehouse and the portico (al-ustuwān) that is in front of the warehouse and it is

4. [The half ] and this warehouse is located in [Yuhannis s]on of Bî̀'a Lūlū's house, and it known that it belongs to 'Ula. This house has four boundaries delimited, the first, the southern ends to

5. [ and its northern boundary ends to ] son of Ishāa and its eastern boundary ends to Shinūda son of Barmūda and its western boundary ends in the neighbourhood of the sons of Ishāa

6. [

] their belongings from this warehouse which is located in Yuhannis son of Bî̀ a Lūlū's house, it is half of it (the warehouse) and the portico (alustuwān), of all of it. 
7. [ Dafqadī and Harmada, the s]ons of Bu[t] ]rus, the son of Kayl and his daughters received this price, which is a dinar and a third, and they have given a quittance to him by means of a receipt, (acknowledging that they had) received and taken (them) over fully, and they hand over to Yuhannis son of Bī'a Lūlū the half

8. [ and he has taken possession of it] and it has become his own [possession], having free disposition of it according to the free disposition of (the) proprietors over their property, and neither of them has any right over the other, and that was in Jumada I of the year three hundred and seventy-one.

9. [Wit]nessed Ahmad son of Darī t[o all] that is contained in this contract and he has written in his own handwriting and thanks to Alla[h] the god of eve[ry]thing.

10. [ ] Fahd son of Musā[f]ir witnessed to all that is contained in this contract and he has written in his own handwriting.

11. [ witnessed] to all that is contained in this [contract and] he has written in his own handwriting. (Vacat) Aḥmad son of 'Abd al-Bar son of R[..a] witnessed on these named persons to all that is contained in this contract.

12. [Witnessed] the herbalist to a[1]1 that is contained in this contract and he has written in his own han[dwrit]ing, and thanks to Allah the true king, who makes all things manifest, in his own handwriting.

\section{Witness's signature opposite to lines 9-10:}

1. 'Abd al-Malik son of 'Abd Allah son of Samīr had witnessed

2. On the buyer and the two sellers' acknowledgment with all that is contained in this

3. Contract and he has written in his own handwriting on its date.

\section{Comments:}

1. Only a lower trace of the mim of $b i$-sm is still visible at the beginning of the first line. The witness, Sa ' $\overline{1} d$, wrote the letters $Y \bar{a}$ ' and $D \bar{a} l$ of his name intertwined, making them resemble a Mim. As the main text's writer, this witness's handwriting is characterised by the backward bending $Y \bar{a}^{\prime}$. It appears three times in his testimony.

2. Because of the severed part at the end of this line, only the lower parts of the letters "Wāw, $R \bar{a}$ ", $H \bar{a}$ " of $k \bar{u} r a$ still exist. "This is what so-and-so bought from so-and-so" was a standard formula at the beginning of sales contracts. ${ }^{1}$ Mentioning the names of the buyer and sellers again is not common in Arabic documents.

4-5. In line four, the letter $W \bar{a} w$ is connected to hadha al-manzil as one word. The buyer's knowledge of what he purchased is a prerequisite for the validity of the contract. ${ }^{2}$ This was one of the reasons that Muslim jurists preferred to mention the four

\footnotetext{
${ }^{1}$ See for example CPR XXVI 7 .2, 333/945, al-Ushmūnayn; P.Fay.Monast 2 .2, 336/947, Naqlūn; P.Cair.Arab. I 63 .3, 434/1043, unknown (al-Fayyūm); P.Berl.Arab. I 20 .2, 448/1065, Țuṭūn; P.GenizahCambr 3 .2, 497/1103-1104, al-Fustāt

2 'Ibrahīm, "Wathīqat bay'", p. 176.
} 
boundaries in the contracts. ${ }^{1}$ The warehouse boundaries followed the usual order; ${ }^{2}$ the south, the north, the east, and then the west. In addition to the borders, the famous name of this house is mentioned as $l i$ - 'Ula. This has been shown in many other examples. ${ }^{3}$ In another example, the famous name of the house was mentioned without mentioning the boundaries. $^{4}$

7. In the south and east of al-Fayyūm, the house prices during the $4^{\text {th }}-5^{\text {th }} \mathrm{AH} / 10^{\text {th }}-11^{\text {th }}$ $\mathrm{AD}$ centuries ranged from 1.3 dinars up to 11 dinars. ${ }^{5}$ However, since there are no other warehouse sales contracts published, we cannot determine whether the price of this warehouse is high. The purpose of the bara' 'at qabd wa- 'istîfa' clause is to confirm receipt of the money owed. It is a very common clause in sales contracts and other documents related to financial matters. ${ }^{6}$ According to al-Samarqandī, if the previous phrase is not mentioned, the words wa- 'abra' tuka (and I granted you quittance) must be written after the indicating receipt of the price, to prove that the receipt of the money and the quittance were at the same time. ${ }^{7}$ As for the delivery and receipt of what was sold, the jurisprudence books indicate that mentioning the receipt of the price must be recorded before mentioning the delivery of what was sold to the buyer. The well-known jurist Malik ibn 'Anas states that if the buyer obtained what he bought with the seller's permission, this is considered as an acknowledgement by the seller that he received the price from the buyer. ${ }^{8}$

8. The date Jumada I 371/ 2 November $981-1$ December 981 is in the reign of the Fatimid Caliph Al- 'Azīz (365-386 AH / 975-996 AD). The purpose of "yahkumu finhi hukm 'arbābi al-amlāki fi 'amlakihim" is to confirm the transfer of ownership and the buyer's freedom to dispose of it as he pleases. ${ }^{9}$ Similar formulas are recorded in many Arab sales contracts. However, it is noticeable that " arbabi al-amlakki" appears only in sales contracts from al-Fayyūm dating to 335-434 AH / 946-1043 AD, ${ }^{10}$ and then it does not appear after that date in the published documents. The purpose of "wa-bari" $a$ ba 'duhum $\min b a^{\prime}$ ' "' is to confirm that both the seller and the buyer have no further

\footnotetext{
${ }^{1}$ Al-Asyūṭ̄i, Jawāhir, vol 1, 76.

${ }^{2}$ In the Demotic, Greek, and Coptic papyri, the boundaries were often described beginning with the south, then the north, the east, and ending with the west. The Arabs followed the same sequence in their papyri. Grohmann's comments on P.Cair.Arab. I $53.2^{\text {nd }}-3^{\text {rd }} / 8^{\text {th }}-9^{\text {th }}$, unknown (Egypt).

${ }^{3}$ P.Chrest.Khoury II. $22.7,1^{\text {st }}-2^{\text {nd }} / 7^{\text {th }}-8^{\text {th }}$, al-Fusțāt; CPR XXVI 13 .5-6, 403/1012, al-Ushmūnayn; P.GottheilSynagogue .31-32, 429/1038, al-Fusțāț; P.Cair.Arab I 64 .10-11, 441/1050, al-Ushmūnayn; P.Cair.Arab I 65 .8, 441/1050, al-Ushmūnayn; P.Cair.Arab I 66 .7, 441/1050, al-Ushmūnayn; P.Cair.Arab I 68 .7, 459/1067, al-Ushmūnayn; P.Cair.Arab I 71 .9-10, 459/1067, al-Ushmūnayn.

${ }^{4}$ P.VanthieghemLocation .3-4, 298/911, al-Ushmūnayn.

${ }^{5}$ For more details see Werner Diem's inventory and the house rent table in Mathieu Tillier and Naïm Vanthieghem's article. Diem, Eine arabische, p. 19; Tillier and Vanthieghem, "Un reçu”, pp. 421-431.

${ }^{6}$ See for example Chrest.Khoury II. 16 .5, 383/994, unknown (al-Fayyūm); P.GenizahCambr. 54 .9, 422/1031, al-Fusțāt; P.RagibQalamun 2 .8, 446/1054, Ṭuṭūn; P.Vente 27 .8, 459/1067, unknown (Egypt); P.KhanQasrIbrim .7, 518/1124, Qașr Ibrīm.

${ }^{7}$ Al-Samarqandī, Al-Surūt, 22.

${ }^{8}$ Al-Tahawī, Al-Shurūt al-Saghīr, vol 1, 9-10.

${ }^{9}$ Such expressions were recorded in Aramaic, Greek and Coptic sales contracts. They all have two syllables, the first referring to the transfer of ownership, and the second to the buyer's rights. Gladys, "A Comparison", Part V, 98-99.

${ }^{10}$ P.Fay.Monast. 1 .13, 335/946, Naqlūn; P.Berl.Arab. I 10 a .16, 406/1015, unknown (al-Fayyūm); P.KölnKauf .11, 413/1024, unknown (al-Fayyūm); P.Cair.Arab I 62 .11, 429/1037-1038, unknown (alFayyūm); P.Cair.Arab I 63 .8, 434/1043, unknown (al-Fayyūm). Except for previous documents, the only document in which this formula was mentioned is: P.Cair.Arab I. 74 .6, 344/955, unknown (Egypt). Since it is dated to the period in which this formula appeared in al-Fayyūm, we suggest that the source of this document is probably al-Fayyūm.
} 
entitlements. Similar formulas appear in other documents. ${ }^{1}$ However, the exact one used in this document does not appear in any other contract.

9-12. Only the lower part of the $B \bar{a}^{\prime}$ of $a l$-kitāb in the middle of the eleventh line still exists. It is known that in Islamic law, the number of witnesses for any contract must not be less than two, and there is no maximum number of witnesses. In this contract, the witnesses signed in the past tense. Ibn 'Ābidin states that one of the testimony conditions is that the witness says 'ashad in the present tense. Moreover, it is not permissible to say shahid in the past tense because the time of the testimony is the present, not the past. ${ }^{2}$ No evidence from the Qur'an or the Sunna supports Ibn 'Ābidin's opinion. Also, the use of the word 'ashad, in the present tense, is subject to jurists' disagreements. $^{3}$

\section{CONCLUSION}

This contract shows that the warehouse sale contracts formulas did not differ from other houses' sale contracts formulas in the same era. They contain the essential elements such as the names of the sellers and the buyer, the warehouse boundaries, the price, the confirmation that both the seller and the buyer have no further entitlements, and the witnesses' testimony.

\footnotetext{
${ }^{1}$ See P.Torrey .7, 205/821, unknown (Egypt), P.Cair.Arab I 67 .16, 412/1021-1022, unknown (alFayyūm); P.Cair.Arab II 138 .10-11, 412/1021-1022, al-Ushmūnayn.

${ }^{2}$ Ibn 'Ābidīn, Radd al-Muhtāe, vol 5, 462.

3 'Ibrāhīm, "Al-Tawthīqāt”, 308-309.
} 


\section{BIBLIOGRAPHY}

1- 'Abd al-Lațīf, M., Al-Mudun wa-l-Qurā al-Mișrya fi al-Bardyāt al- 'Arabìya, Cairo, 2012.

2- Al-Asyūṭ̂̄, Sh., Jawāhir al- 'Uqūd wa-Mu'ìn al-Qudāt wa-l-Mūqi ìn wa-l-Shuhūd, Cairo, 1928.

3- Al-Kindī, A., Al-Wulāt wa-l-Qudāt, Beirut, 2003.

4- Al-Nābulsī, A., Tārīkh al-Fayyūm wa-Bilādih, Cairo, 1898.

5- Al-Samarqandī, Al-Surūṭ wa-l-Wathāi 'q, Beirut, 2004.

6- Al-Tahāwī, A., Al-Shurūṭ al-Saghīr, Baghdad, 1974.

7- Ibn al-Jā̄'ān, Sh., Al-Tuhfa al-Sanya bi- 'Asmā'i al-Bilad al-Mișrya, Cairo, 1898.

8- Ibn 'Ābidīn, M., Radd al-Muhtār 'alā al-Durr al-Mukhtār, Beirut, 1992.

9- 'Ibrāhīm, 'A., "Al-Tawthīqāt al-Shar' īya wa-1-'Ishhādat fi ẓahr Wathīqat al-Ghūrī”, Bulletin of the Faculty of Arts, Cairo University 19, 1 (1957), 293-420.

10- 'Ibrāhīm, 'A., "Wathīqat bay', Bulletin of the Faculty of Arts, Cairo University 19, 2 (1957), 135-214.

11- CPR XVI = Diem, W., Arabische Briefe aus dem 7. - 10. Jahrhundert, Wien-Hollinek, 1993.

12- CPR XXVI = Thung, M., Arabische juristische Urkunden aus der Papyrussammlung der Österreichischen Nationalbibliothek, München, 2006.

13- Frantz-Murphy, G., "A Comparison of the Arabic and Earlier Egyptian Contract Formularies, Part I: The Arabic Contracts from Egypt (3rd/9th-5th/11th)", Journal of Near Eastern Studies 40 (1981), Chicago, 203-225.

14- Frantz-Murphy, G., "A Comparison of the Arabic and Earlier Egyptian Contract Formularies, Part II: Terminology in the Arabic Warranty and the Idiom of Clearing/Cleaning", Journal of Near Eastern Studies 44 (1985), Chicago, 99-114.

15- _., "A Comparison of Arabic and Earlier Egyptian Contract Formularies: Part IV: Quittance Formulas”, Journal of Near Eastern Studies 47 (1988), Chicago, 269-280.

16- _. "A Comparison of Arabic and Earlier Egyptian Contract Formularies: Part V: Formulaic Evidence”, Journal of Near Eastern Studies 48 (1989), Chicago, 97-107.

17- Foss, C., "Egypt under Mu'āwiya, Part I: Flavius Papas and Upper Egypt”, Bulletin of the School of Oriental and African Studies 72 (2009), London, 1-24.

18- P.Berl.Arab. I = Abel, L., Ägyptische Urkunden aus den königlichen Museen zu Berlin: Arabische Urkunden, Berlin, 1896-1900.

19- P.Cair.Arab = Grohmann, A., Arabic Papyri in the Egyptian Library, Cairo, 1934-1962.

20- P.Chrest.Khoury II = Grohmann, A\& Khoury, R., Papyrologische Studien: Zum privaten und gesellschaftlichen Leben in den ersten islamischen Jahrhunderten, WiesbadenHarrassowitz, 1995.

21- P.FahmiTaaqud = Fahmī, 'A., "Wațā' iq li-1-Ta āqud min Fajr al-Islām fi Mișr”, Bulletin de l'Institut égyptien 54 (1972-1973), Cairo, 1-58.

22- P.Fay.Monast = Abbott, N., The Monasteries of the Fayüm, Chicago, 1937.

23- P.GenizahCambr = Khan, G., Arabic Legal and Administrative Documents in the Cambridge Genizah Collections, Cambridge Library, Cambridge 1993.

24- P.GottheilSynagogue = Gottheil, R., "An Eleventh-Century Document Concerning a Cairo Synagogue”, Jewish Quarterly Review 19, (1907), 467-539. 
25- P.JoySorrow = Younes, Kh., Joy and Sorrow in Early Muslim Egypt: Arabic Papyrus Letters: Text and Content, Leiden, 2013.

26- P.KhanQasrIbrim = Khan, G., "The Medieval Arabic Documents from Qasr Ibrim". In van der Vliet. J and Hagen J. L. (eds.), Qasr Ibrim, between Egypt and Africa: Studies in cultural exchange, Nino Symposium, Leiden, 11 - 12 December 2009, (Leiden: Nederlands Instituut voor het Nabije Oosten; Leuven: Peeters, 2013), 145-156.

27- P.KölnKauf = Diem, W., Eine arabische Kaufurkunde von 1024 n. Chr. aus Ägypten: Aus der Sammlung der Max-Freiherr-von-Oppenheim-Stiftung, Wiesbaden - Harrassowitz, 2004.

28- P.RagibQalamun = Rāìib (Yūsuf), "Les Archives d'un Gardien du Monastère de Qalamūn", Annales islamologiques 29 (1995), Cairo, 25-57.

29- P.Torrey = Torrey, Ch., "An Arabic Papyrus Dated 205 A. H", Journal of the American Oriental Society 56, 2 (1936), New Haven, Conn., 288-292.

30- P.VanthieghemLocation = Vanthieghem, N., "Contracts de Location Arabes I: Un Contrat de Location d'une Maison en Arabe (P. Brux. Inv. E. 8449)". Chronique d'Egypte 88, (2013), Brussels, 188-197.

31- P.Vente = Rāgiib, Y., Actes de Vente d'Esclaves et d'Animaux d'Égypte Médiévale I, Cairo, 2002.

32- Ramzī, M., Al-Qamūs al-Jughrafì, Cairo, 1994.

33- Tillier, M \& Vanthieghem, N., "Un Reçu de Paiement pour une Vente Immobilière à Terme)", Chronique d'Egypte 93 (2018), Brussels, 421-431.

\section{Websites}

http://www.naher-osten.Imu.de/isapchecklist [Access Date: March 3, 2021] 